\title{
Article \\ The disturbing object of philology
}

\author{
Vincent W.J. Van Gerven Oei \\ Tembusu College, National University of Singapore, Singapore.
}

\begin{abstract}
This essay investigates a certain disturbance that appears at the moment that philosophy is confronted with philological practices, as foreshadowed in Paul de Man's seminal work on the 'return to philology.' This disturbance appears vividly in Heidegger's Introduction to Metaphysics with the sudden appearance of the 'nonsense word' kzomil. Heidegger's invented word suggests that philology is not immune to its own unsettling techniques, as is also evident in Gerald M. Browne's study of the Old Nubian language. Ironically, we can characterize the object of philology more precisely by turning away from ancient texts and toward Nathaniel Mellors's absurdist television series Ourhouse.
\end{abstract}

postmedieval: a journal of medieval cultural studies (2014) 5, 442-455.

doi:10.1057/pmed.2014.32

We did not just talk ourselves into this. -Martin Heidegger

Ever since the publication of Paul de Man's seminal text on 'the return to philology,' there has been the question of the precise object of this philological practice founded on reading - on 'an examination of the structure of language prior to the meaning it produces' (De Man, 1986, 24). Such a philology could, strictly speaking, by nature of this 'prior,' no longer have language as its object in the sense that linguistic theory would. In an elaboration of De Man's return, Werner Hamacher suggests that 'only one half of language is an ontological process; philology must, therefore, also concern itself with the other half' (Hamacher, 2009, 33) ['Sprache ist nur halbwegs ein ontologische Prozeß; die 
Philologie hat sich auch mit der anderen Hälfte zu befassen'] (Hamacher, 2010, 50). Whereas Hamacher consequently characterizes language not as an object but as objeu of philology, ${ }^{1}$ the present paper approaches the question of the philological object from a different direction, namely by showing how the deliberate construction of the object - whether anchored in philosophical or classical philological discourse - cannot but have disturbing consequences.

In order to approach the philosophical side of the issue, consider Martin Heidegger's comments about reading words in Introduction to Metaphysics:

'[T]o be' [Sein], when written and seen, is different at once from 'kzomil.'

This written mark is also a sequence of letters, of course, but one by which we are unable to think anything. There is no such thing as an empty word only one that is worn out, yet remains full. The word 'Being' retains its naming force. The slogan, 'Away from this empty word "Being," towards the particular beings!' is not only an overhasty but a highly questionable slogan. (Heidegger, 2000, 83) ${ }^{2}$

Why is Sein offset with this kzomil, 'the word by which we are unable to think anything'? Heidegger, who otherwise is able to access the minute details and inflections of words, up to and including the word Sein, here establishes something of the differend of Sein. Kzomil is a truly empty word in the sense that it doesn't give anything to thought, yet 'there is no such thing as an empty word.' How then to read this, leaving aside the problematic question of how to translate it from German to English (is the difference between kzomil and Sein different from the difference between kzomil and Being)?

What could have pushed Heidegger to suggest this so-called empty word that nevertheless by and large seems to follow the syllabic structure of German? In order to find out we need to backtrack slightly to Heidegger's initial investigation of the word 'Being'. In the chapter preceding the one in which he coins kzomil to offset Being as 'meaningful,' he tries in vain to ground the meaning of Being in etymological or grammatical considerations. Heidegger starts out the chapter 'On the Grammar and Etymology of the Word "Being"' with a conditional statement: 'If for us Being is just an empty word and an evanescent meaning, then we must at least try to grasp fully this last remnant of a connection' (Heidegger, 2000, 55). What follows is an aporetic consideration of the determination of Sein as a grammatical form, into the realm of the etymology of the different stems of the Indo-European words for 'to be.' He concludes:

(1) The grammatical examination of the form of the word had this result: in the infinitive, the word's definite modes of meaning are no longer in effect; they are blurred. [...] (2) The etymological examination of the meaning of the word had this result: what we today, and for a long time previously, have called by the name 'Being' is, as regards its meaning, a blending that levels off three different stem meanings [...]. This blurring and blending go
1 'Objeu is the object that preserves in play its freedom not to ossify into the object of a subject. It is the counterplay against the objectification of a thing by naming it' (Hamacher, 2009, 33) ['Objeu ist das Objekt, das im Spiel seine Freiheit bewährt, nicht zum Gegenstand eines Subjekts zu erstarren. Es ist das Widerspiel gegen die Vergegenständlichung einer Sache durch ihre Benennung'] (Hamacher, 2010, 52).

2 According to Jacques Derrida, the Introduction to Metaphysics is the moment from which 'Heidegger renounces the project of and the word ontology' (Derrida, 1976, 22), leading all the way to the crossing out of the word 'Being' in the Question of Being. The onset of this movement is already apparent in this passage. 
3 Another option would be to situate a certain accessible Absolute outside the realm of language (as several contemporary philosophical movements suggest).

4 See the work of Avital Ronell, throughout an affirmation of the potential of strategies of deliberate overreading (1989, 2007). hand in hand. The combination of these two processes provides a sufficient explanation for the fact from which we set out: that the word 'to be' is empty and its meaning is evanescent. (Heidegger, 2000, 77-78)

Having failed to ground the meaning of Being in any etymological or grammatical categories, Heidegger exclaims, 'away from the empty schema of this word "Being"!' (Heidegger, 2000, 80). And escaping this emptiness, he invents the word kzomil, which 'when written and seen, is different at once' from Being (Heidegger, 2000, 83; my emphasis). In other words, in order to escape the emptiness pervading grammatical and etymological categories, Heidegger refers to reading and writing to save Being, because 'There is no such thing as an empty word. [...] The word "Being” retains its naming force' (Heidegger, 2000, 83). What if kzomil here is nothing but the effect of reading, as a disturbance produced by the introduction of the reading act - 'written and seen'? A meaningless word as an effect of the reader's attention to the fact that it is reading the word 'to be' that gives it sense? The fact that Heidegger avoids any further engagement with kzomil, even up to the point where the word is merely 'seen' and not even properly 'read,' may be an indication. Nevertheless, the fate of language as a whole depends on the meaning of Being that is guaranteed by kzomil: 'Suppose that there were no indeterminate meaning Being, and that we did not understand what this meaning signifies. Then what? Would there just be one noun and verb less in our language? No. Then there would be no language at all' (Heidegger, 2000, 86; emphasis in original).

It is in relation to this rhetorical move toward the onset of reading, seeing a written mark, and Heidegger's immediate retraction from it, that I would like to situate De Man's 'Resistance to Theory.' In this text he addresses precisely the issues that arise in the theoretical movement from grammar to reading at work in these sections of the Introduction to Metaphysics, even if largely glossed over by Heidegger himself. It is also within this field of tension that I would like to place the philological tradition of the medieval African language of Old Nubian, even though this work, for the moment, still seems far removed from our current considerations.

According to De Man, 'as long as it remains grounded in grammar, any theory of language, including a literary one, does not threaten what we hold to be the underlying principle of all cognitive and aesthetic linguistic systems' (De Man, $1986,14)$. We could wage the claim that classical metaphysics (any metaphysics of presence) largely adheres to such a grammar-dependent system. To move beyond grammar means to enter the domain of 'reading,' an act, however, 'that is systematically avoided' (De Man, 1986, 15). ${ }^{3}$ Apart from the evidence provided by the above passage from the Introduction to Metaphysics, the hostility that is still felt toward the different modes of what has been called 'deconstruction' sometimes even branded 'over-reading ${ }^{4}$ - indicates the continuing existence of such systematic avoidance.

Nevertheless, apart from certain areas of continental thought, there is another realm - precisely the realm alluded to by De Man - that to a certain extent has 
embraced 'reading' (De Man, 1979), namely literary studies as an inflection of philology. Although De Man was mainly concerned with literature, we may extend his observation to the classical realm of philology from which he derives his theoretical apparatus. And indeed we find that several scholars from the field of classical philology have attempted to embrace certain deconstructive practices, precisely because of their attention to reading. Here we may point to the invitations formulated by Alexander Gurd in his plea for a 'radical philology.' This philology, grounded in specifically Derridean terms such as iteration and dissemination, proposes textual criticism to be 'the substance of ancient literature, not a tool used to recover it' (Gurd, 2005, 45). And: 'Any edition or text may be "polysemous" when read by interpreters; but it is in the hands of the textual critic that texts disseminate themselves' (Gurd, 2005, 46). Gurd proposes a series of readings of the different sources, manuscripts and palimpsests underlying any historical textual entity as constituting the philological practice of 'establishing' a text, that is, as textual multiplicity, moving beyond the grammatically constrained 'received texts.' From another perspective, Hans Gumbrecht expands the modes of philological research precisely by appealing to De Man's 'literary reading' as proximate to the types of reading that are already at work inside philological practice, even though he never specifically addresses the differences (Gumbrecht, 2003, 35).

These two approaches to contemporary philological practice, from the side of literary studies and classical philology, respectively, strengthen its bond with a certain philosophical development; they are not without predecessors and antecedents of their own and in no way do justice to the wide variety of philological approaches - including the ones that are thoroughly critical toward any 'theory' at all. ${ }^{5}$ Nevertheless, they indicate a certain future for philology that would bring it again in closer alliance with philosophical practice, an alliance that I would love to see flourish. This alliance, though, may never be allowed to consist in solely the appropriation of modes of reading developed outside classical philological practice - as in our examples De Man and Derrida - without a reciprocal demand, from the side of philosophy, to question any appropriative strategy deployed by philology.

If we would follow De Man's argument, it would be impossible to 'just' apply a theory of reading to classical texts without producing side effects. Such an application necessarily produces a 'disturbance' that remains unnoticed on the seismic monitors of both Gurd and Gumbrecht. According to De Man:

This undoing of theory [i.e., reading], this disturbance of the stable cognitive field that extends from grammar to logic to a general science of man and of the phenomenal world, can in its turn be made into a theoretical project of rhetorical analysis that will reveal the inadequacy of grammatical models of non-reading. (De Man, 1986, 17)

Going back to the passage of Heidegger that I quoted at the opening of this essay, the materialization of this 'disturbance' introduced by the (disavowed) practice of
5 For example, Martin West:

'Textual criticism is not something to be learned by reading as much as possible about it. Once the basic principles have been apprehended, what is needed is observation and practice, not research into the further ramifications of theory.' And E.J. Kenney: 'the theorists ... have generally speaking not edited texts or have not done so with much distinction; the best practitioners have fought shy of methodizing and mechanization' (both cited in Gurd, 2005, 41). 
reading suddenly and unconsciously inserted into his philosophical argument after the collapse of etymological and grammatical discourse is precisely the 'empty word' kzomil. Heidegger, with De Man after him, registers the insufficiency of grammatical analysis in his interpretation of Being, and provides - intuitively, accidentally? - an onset toward a reading interpretation: writing and seeing.

On the surface, however, it does not seem to be the case that such disturbance, which De Man calls 'resistance to theory,' appears in either Gurd or Gumbrecht. Classical philology remains relatively undisturbed by the introduction of elements of 'reading' or 'deconstruction,' simply because such elements seem to have always already been present in philology. In other words, philology has already been disturbed. What then is this disturbing object, or rather, what is the kzomil of classical philology?

$* * *$

Philological practice, concerned as it is with marginality, textual/grammatical apparatus and footnotes, is founded upon a study of occidental documents. Any application of its techniques - fine-tuned for a specific set of materials and languages - outside its original realms causes a friction that seems to be largely glossed over within philology whenever it focuses on its Greek and Latin fields of interest. A first indication of this friction is, for example, present on the title page of Martin West's standard introduction to philological technique, Textual Criticism and Editorial Technique, which suggests that it is only 'applicable to Greek and Latin texts' (West, 1973). As a specific mode of interaction with language, philology is grafted onto philosophically oriented categories like nouns, verbs, inflections and sentences. Although certain Near-Eastern, nonIndo-European literary traditions such as Aramaic and Coptic have been able to integrate themselves relatively smoothly into the paradigms of occidental philological practice - they were already known by the time philology first blossomed and their grammatical differences have been accounted for and incorporated within occidental grammar - there is one language that appeared on the scanners of scholarship long after the last, Romantic revival and rejuvenation of philological interest in 'the Orient.'

Old Nubian entered occidental philological discourse at the beginning of the twentieth century, in a collection of material published by Griffith (1913). The Old Nubian corpus, which dates from the eighth to the fifteenth century, consists largely of material that seems familiar: half Christian texts, half documentary texts such as contracts, all written in a derivative of the Greek alphabet. No extensive decipherment had to take place, as there were several living Nubian languages in Northern Sudan to compare the material with - so it was thought that Old Nubian was accessible to philology. Whereas other languages and traditions, like the Sumerian or Chinese, may find themselves at a comfortable remove from western philological practice, either temporally or spatially, Old Nubian literary texts insinuate themselves within this practice and are therefore 
forced to engage with it, even though, linguistically speaking, they are heir to a tradition of which the only (and sparsely attested) predecessor is Meroitic (Rilly, 2010).

Not only the time frame of Old Nubian, prior to its philological discovery, is sealed off. We are also almost certain that no more material written in Old Nubian will ever surface apart from the documents still stored in Oxford archeological archives and inadequately labeled boxes under the staircases of Egyptian museums: the entire area that once was home to the center of Nubian civilization has become inundated after the construction of the Aswan Dam on the Nile. The Old Nubian language, although far from a grammatical and stylistic unity, therefore offers itself as a limit case for classical philological practice: determinate in time and space and with a relatively small volume of a few hundred pages, it seems to offer enough possible parallels to canonical texts, yet remains stimulatingly unfamiliar.

Earlier I referred to the fact that classical philology has not displayed a 'resistance to theory' similar to the one that is still so acerbically haunting philosophy. This may have been caused by a continuing practice of relying mainly on grammatical and etymological evidence (or proceeding through the actual materials), where acts of reading are institutionalized within a strictly organized apparatus. This stable confinement of any potential disturbance, however, is shattered at the moment that classical philology leaves its confines and is confronted with an object it cannot, strictly speaking, read: the Old Nubian text. Not only do grammatical, etymological and lexicographical categories break down in the face of Old Nubian textual material, but it also threatens the continuity that has cushioned the proliferation of philology from classical texts toward the study of classical texts.

One of the many testimonies to this difficulty that will remain insurmountable for us is the essay 'Old Nubian Philology' by the classical scholar Gerald M. Browne, who once stated: 'About Old Nubian I have only to say that I pursued it for the same reason that I bought a Yugo: I felt it needed me' (Bay, 2006, 7). Apart from the possible readings of investment and the figure of speech that implies a constitutive link - 'the only thing he has to say' - between acquiring a car and adopting or caring for a language, it remains a fact that Browne singlehandedly inserted Old Nubian into the field of classical philology.

Browne opens his article as follows: 'My title is deliberately ambiguous: it means not only the modern philologist's approach to Old Nubian, but also philology as once practiced in Nubia' (Browne, 1985, 291). This first sentence immediately suggests that any contemporary philological practice is predicated on the prior existence of such practice at work within the material that is approached and appropriated by philology. Classical philology is able to deal with the issues of grammar and rhetoric because these have always already been a concern of the textual material. However, for philology to remain 'operable' in this sense, such an activity needs to be assumed for any corpus - including the Old 
Nubian one - at the risk of the total breakdown of the fields of grammar and rhetoric. The access to grammar would somehow precede grammar itself.

Browne assumes a philological practice in Nubia, based on 'two passages in the texts which appear to reflect a rather high level of philological expertise on the part of the Nubian translators' (Browne, 1985, 291). These translators purportedly translated from Greek to Old Nubian, thus offering a link between Greek and Old Nubian philological practice that would legitimate, in its turn, Browne's philological intervention from out of the domain of classical philology, thus limiting the possibly poisonous side effects of a reading that would depart from a different, less convoluted structure or tradition. He strengthens his assumption of the existence of Old Nubian philology by the positing of 'an impressive Nubian library.' The papyri found in the Cathedral of St Mary the Virgin in the Qasr Ibrim, which are commonly referred to as P. QI (Browne and Plumley, 1988), supposedly belonging to this library would '[n]ot only [...] substantially increase our knowledge of the Nubian language, in two places - the first in Text 1 , the second in Text 9 - they appear, if I have properly interpreted them, to attest to an interest taken by their translators in matters philological' (Browne, 1985, 292). Browne's act of interpretation rapidly moves beyond the texts to project 'translators' interested in 'matters philological.'

The first text, $P$. QI 1.9, is identified by Browne as a translation of a part of Rev. 14:6-15. He states the following: '[I]ts evidence is quite straightforward, though the interpretation less so' (Browne, 1985, 292). Let us put aside the difference that Browne suggests between 'evidence' and 'interpretation,' which evokes the classical separation between recensio and examinatio, as this supposed difference is not constitutive of his argument. In order to facilitate an interpretation that would bring forward an Old Nubian philological tradition, Browne does not start by citing the Old Nubian fragment, but rather with the Greek text from the Textus Receptus, which he calls, parenthetically, 'a convenient point of departure' (Browne, 1985, 292). We are left to gather the Old Nubian text from another publication:

oulgrikon einise ilka harmla pesin aigille: paeso agendegouelo dilgoul diragouesin nollokō dieigoul elekkan alo pessna seuartil, tan korpajjigoulo paja nesakkoannoa yeserannojoun, ten yeeigoullon tekka ergijona harmikiskil. (Browne and Plumley, 1988, 57 [P. QI 1 9.ii.11-13]; transliterated from the original script)

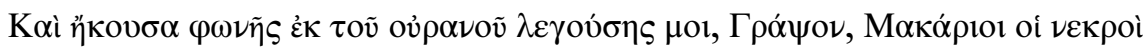

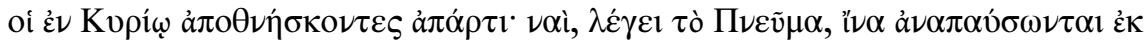

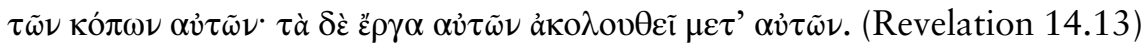

['And I heard a voice from heaven, saying unto me, Write, Blessed are the dead which die in the Lord from henceforth: Yea, saith the Spirit, that they may rest from their labours; and their works do follow them.']

(King James Bible) 
Without bothering to read the Old Nubian passage as a whole, Browne jumps onto the 'translation' of the Textus Receptus wording í $\alpha$ á $\nu \alpha \pi \alpha v \sigma \omega \nu \tau \alpha l$ in the Old Nubian text, supposedly rendered by yesakkoannoa yeserannojoun. Based on the repeated verbal root yes, Browne concludes that the scribe must have given two alternatives based on different variations of the Greek Vorlage (the translation's prototype), namely the in $\alpha$ á $\nu \alpha \pi \alpha v \sigma \omega \nu \tau \alpha l$ of the Textus Receptus and a ö $\tau$ á $\alpha \pi \alpha \dot{o} o \nu \tau \alpha l$, a 'hitherto-unattested but hardly surprising combination' (Browne, 1985, 292). His interpretation is as follows:

In a stage of textual transmission prior to what we find in our Nubian manuscript, yesakkoannoa 'in order that they may cease' may be presumed to have stood alone in the text, as representing the widely attested i $\nu \alpha$ á $\alpha \pi \alpha v \sigma \omega \nu \tau \alpha$, while yeserannojoun 'because they cease' was added, most likely in the margin, as a variant reading. Later - in the stage represented by the Qasr Ibrim piece - a scribe simply incorporated the marginal variant into the body of the text. The fact that the Nubian piece displays a variant reading may imply a certain amount of philological awareness on the part of its translator: we can readily imagine that he had access to at least two Greek manuscripts and sought to represent their salient textual differences.

(Browne, 1985, 293)

Browne's misinterpretation of the repetition as a philological exercise is based on his failure to account for the transitivizing suffix -ar, assimilated to $-a k$, preceding the final suffix -koannoa. The verb form yesakkoannoa implies that something is ceased, put down, namely their korpajjigoulo, or labors. The first instance of the verb therefore refers to the putting to rest of work, whereas the second instance refers to the resting of the dead themselves. Whereas the Greek medial construc-

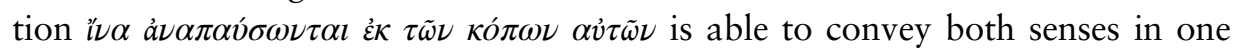
verb, such construction is absent in Old Nubian and perhaps the scribe found it necessary to be more explicit.

Moreover, Browne decides to ignore the other anomalies in the Old Nubian rendering of the passage from Revelation, for example, the addition of 'many' [dieigoul], the erroneous spelling of 'their' as tan and the addition of harmikiskil ['up to heaven'] in the last line. All in all, this is enough evidence to suggest that perhaps something other than intense philological activity was taking place. It remains unclear whether we are dealing with philological practice or scribal invention.

We can also readily picture Browne 'imagining' the Nubian scribe, bent over his Greek manuscripts, working within the philological tradition that he holds so dear. Nevertheless, 'in absence of proof, we can do no more than tentatively suggest that the translator's motivation was philological' (Browne, 1985, 293). But why then this imagination? Why this tentative suggestion in absence of proof,' even though the 'evidence is quite straightforward'? Was it perhaps Browne himself who 'heard a voice from heaven, saying unto him, Write'? No further reasons are given for these philological reveries. Instead, he continues with 
a 'second passage of interest in this discussion of possible philological activity in Nubia,' in which he discusses the possible influence on the Nubian translator's work of Origen's Hexapla, 'clearly an esoteric reference work, obviously not intended for general circulation'; we thus have 'evidence of more than ordinary scholarship.' He infers this access to philological resources from the fact that several elements in the (damaged) Old Nubian translation of verse 9 of Psalm 31 deviate from the Septuagint version in a way not unlike Symmachus's Greek translation of the same psalm. But 'indeed,' he states in a footnote, 'it is also possible that the translator merely rendered a Greek version already influenced by the Hexapla' (Browne, 1985, 293).

Once again, Browne's textual evidence is flimsy, relying on tentative restorations. Nevertheless he claims that ' $[\mathrm{t}]$ his passage from the Psalms, together with that previously discussed from Revelation, suggests - if my interpretations are correct - that the Old Nubian translators had some training in philological method' (Browne, 1985, 295). Here we encounter the culmination of Browne's own rhetorical collations. Not only does he posit - without reservation 'ordinary scholarship' and the existence of 'Old Nubian translators'; they even had 'some training in philological method,' a method that Browne at the same time is extremely eager to apply to a corpus that seems to resist it with all its grammar and style. This resistance not only destabilizes the boundaries between grammar and style but also constantly forces Browne to relegate thorny grammatical issues to style and rhetoric. He even has to stabilize his analyses with retro-translations from the Old Nubian reconstructions to Greek or Coptic Vorlages. For example, Browne justifies his retro-translation of The Old Nubian Miracle of Saint Menas as follows:

The most convincing proof [i.e., more convincing than linguistic and contextual evidence] of a Greek Vorlage for the Nubian tale is the ease with which the latter can be turned into the former: the text is unusually susceptible to a literal retroversion into Greek comparable to the vulgar idiom of Pomjalovskij's miracle stories, as the reader can see for himself by examining the hypothetical reconstruction of the Greek that I have printed below the transcript of the Nubian. Though convinced of a direct Greek model for our text, I nevertheless merit the view that the Greek may have derived from a Coptic archetype, and for the curious reader I have attempted a reconstruction of this archetype.

(Browne, 1994, 3-4; my emphasis)

Thus Browne reconstructs not only the Greek Vorlage, but also a hypothetical Coptic archetype of the Vorlage itself! By constructing this hypothetical tradition of translation to serve as a buffer between the extreme foreignness of Old Nubian and the comfort of the familiar grammatical territories of Greek and Coptic, he enables himself to be a mediator for the philological tradition that legitimates his own access to those texts. In fact we could claim, with Giorgio Agamben, that for Western 
culture this is the only method through which such mediation could take place: 'In our culture, which lacks specific categories for spiritual transmission and exegesis, it has always fallen to philology to guarantee the authenticity and continuity of the cultural tradition' (Agamben, 2007, 162). We are witness to a situation in which the classical methodology of recensio and examinatio collapses: the derivation of the Old Nubian text from the Greek consistently interferes with examination of the relation between the Old Nubian and the imaginary Greek Vorlage.

Faced with these delirious moves, we in our turn may refer again to Gumbrecht, who states that 'Philological resistance to theory [...] would be the name for a desire to identify with what does not lend itself to identification and, as a consequence, a name for a lack of tact that threatens to transform the texts to be edited into the editor's own texts' (Gumbrecht, 2003, 36). Browne's insistence on a Nubian philological tradition can therefore be captured in what De Man refers to as an 'undue phenomenalization or [...] any undue grammatical or performative codification of the text' (De Man, 1986, 19). This phenomenalization of 'the inadequacy of grammatical models of non-reading' (De Man, 1986, 17) results from the barriers that do not allow an effective reading of the Old Nubian corpus. We could therefore consider the spectral appearance of fully and properly readable Vorlages in Browne's work on Old Nubian as such phenomenalizations. Imaginary texts regulate the access to unreadable meaning.

The last paragraph of Browne's essay finally points to the underlying desire that has been motivating his entire essay, the desire of the philologist. After referring to 'a more pertinent analogue' of a scribe stuck in the 'Egyptian village of Karanis, an outpost of civilization on the verge of the Fayum's inhospitable desert' (Browne, 1985, 296), he states:

I have the feeling that the men who translated Greek in Medieval Nubia would have been sympathetic with the Egyptian scribe's plight. Cultural wastelands can often be conductive to the refinement of intellectual pleasures: faced with a bleak and dismal landscape, the mind seeks solace within itself, and the gentle art of philology - as I have learned from practicing it in an area culturally not unlike Nubia - is a remarkably effective anodyne for boredom and despair. (Browne, 1985, 296)

Perhaps we should only admire Browne's candor (or just plain bathos) in this final passage, but it points toward more than a personal predicament. Old Nubian, in its writing and in its content, seems to suggest that such an identification between philologist and scribe, reader and writer, is possible, or at least allows itself to be interpreted as an opening toward an identification to come. But it turns out that instead of welcoming the philologist with the warm familiarity that has been transmitted ever since the earliest Greek sources, he is radically obstructed. And on the edge of the impossibility to identify, there is, I think, a true possibility to rethink the grammatical, etymological and rhetorical practices that philology takes for granted - a rethinking that hopefully will attain the same depths as the 
6 The sequence can be viewed on

Nathaniel Mellors's Vimeo page: https:// vimeo.com/ 53407537 (from 24'00' onward). See also Ronell (1989) for an analysis of telephony on which we silently rely. ones Heidegger was propelled to in his consideration (and final crossing out) of Being after his confrontation with kzomil.

$$
* * *
$$

To conclude this text, as a sort of reprise, but also to open it up to a possible direction that philology allied with philosophy might take, I would like briefly to address the work of the British artist Nathaniel Mellors. In an interview with Nicolas Bourriaud, Mellors states that his 'narratives are played out in scenarios where the relationship between word and external reality has often slipped, or is in the process of slipping, further away from sense.' The characters wrestle with this 'confusion' and he is 'particularly interested in the systematic disconnection of a collective and consensual measure of reality through language' (Bourriaud, 2010, n.p.). In another interview he suggests: 'my means of responding is in the idea of language as a kind of currency, to make a subject of the manipulating of language' (Mellors and Wright, 2012, n.p.). Mellors's properly philological investigations of language, which he gathers under the term 'scriptwriting,' are launched systematically throughout his oeuvre along several trajectories that traditionally form the (disavowed) limits of philological inquiry: time, pain, circulation.

We may start to trace one of these philological limits by inspecting one of Mellors's works as documented in the Book A or Megacolon or For \& Against Language, namely Ourhouse (2010). In doing so, we may hope to engage in an exercise that is 'post-philological,' as Michelle Warren suggests: 'The postmodern gesture of philology lies in removing the idea of a privileged center from the conception of critical practice and in analyzing the symptoms of desires for original artifacts - desires that permeate philology, modern aesthetics, and colonial power relations alike' (Warren, 2003, 36).

In Ourhouse, a television series based on the popular sitcom format, Mellors reaches one of the clearest articulations of what we may venture to call his kzomilitant approach - a militancy for that 'by which we are unable to think anything' (Heidegger, 2000, 83) - where Heidegger's last resort to save Being from meaninglessness, and Browne's imaginary philological tradition, materializes into 'The Object.' The first episode of Ourhouse opens with a sequence of scenes obsessed with recording and reading, from the opening sequence where a spelling bee becomes a scene of torture and abuse, Daddy's injunction that '[u]ndocumented experience is life thrown down the lavatory' (Mellors, 2010, 157), and the scene in which he reads a cryptic letter under water until it dissolves (Mellors, 2010, 162). The scenes leading up to the discovery of 'The Object' establish an environment of interrupted transmissions and misconnecting switchboards. ${ }^{6}$ We cut from a scene in which Daddy and Babydoll discuss a number of her art objects in an empty gallery space, speaking in a total parody of International Art English. Daddy points to a q-tip sticking out of the wall:

Daddy: Hmmmmmm. Hmmmmmmm. This, this! (pointing) I absolutely love this. It makes it! What were you thinking with this? 
Babydoll: It's - broadcasting. That part is broadcasting.

Daddy: Genius. (Mellors, 2010, 175)

We cut to Truson, struggling to install an answerphone system, a figure of shortcircuiting signals and closing down the lines of incomprehensible communication (Mellors, 2010, 168). The phone rings, and Truson 'feels compelled to speak' (Mellors, 2010, 176):

Suddenly, as if a switch were flipped, his awareness of The Object is activated. He can see something alien in the room. He drops the phone. It is tangled with the answerphone and bounces and dangles on its cable. Truson opens his mouth and eyes wide in terror then unleashes a tremendous and continuous scream which rattles through the house.

Truson: Argghhhhhhh! (Mellors, 2010, 176)

The various family members hear his scream and enter the room with 'The Object.' However, staring intently at it, no one is able to see it for what it is. In fact, their communication falls apart into an incoherent exchange. Here the entire apparatus of Mellors's kzomilitancy becomes apparent:

Truson (anxious, mechanical, smiling): I can't hear it above 8 miles. Silent, and approximate point of feedback of less than one inch above 300 megahertz. It is the sound of death, feeling, death, feeling, it's a frequency it has a bandwidth and we could make a radio station for it we could make dead radio if we weren't inside the mirror. If we could break the composite we could make it. It can't think outside the loop. Help me.

$$
\text { (Mellors, 2010, 184-185) }
$$

'The Object' in Ourhouse presents a real and definitive obstacle to the full production of language - it cannot be properly read - and in its interaction with the characters in Ourhouse reveals each one of them as animatronic sculptures in which language suddenly becomes completely divorced from the body. It is an object - alternately guessed as 'hourglass,' 'cypher' and 'reaper' - incessantly devouring and puking out entire libraries without ever allowing for a direct line of communication. It is trapped in a loop and only a dead radio station may dream of catching its airwaves. Mellors's Object is, in other words, yet another allegory for the object of philology: that which it cannot yet read but must. ${ }^{7}$

\section{About the Author}

7 I wholeheartedly affirm here Werner Hamacher's dictum 'Language is imperative' $(1996,201)$.

Vincent W.J. Van Gerven Oei has studied composition, linguistics, conceptual art and philosophy. He has translated work by Jean Daive, Alessandro De Francesco, Hervé Guibert, Avital Ronell, Nachoem Wijnberg and Werner Hamacher, among 
others, and his writings have appeared in theory and literary journals. Van Gerven Oei is Visiting Fellow at Tembusu College, National University of Singapore, director of the arts and humanities research platform The Department of Eagles and runs the multilingual publishing house Uitgeverij. He lives and works in Tirana, Albania (E-mail: vincent@vangervenoei.com).

\section{References}

Agamben, G. 2007. Infancy and History: On the Destruction of Experience, trans. L. Heron. London and New York: Verso.

Bay, S.M. 2006. In Memoriam: Gerald M. Browne. Beiträge zur Sudanforschung 9: 5-7.

Bourriaud, N. 2010. Interview with Nathaniel Mellors. SMBA Newsletter 110, http://www .smba.nl/static/en/exhibitions/giantbum/smba-newsletter-110.pdf.

Browne, G.M. 1985. Old Nubian Philology. Zeitschrift für Papyrologie und Epigraphik 60: 291-296.

Browne, G.M. 1994. The Old Nubian Miracle of Saint Menas. Beiträge zur Sudanforschung Beiheft 7. Vienna: Wien-Mödling.

Browne, G.M. and J.M. Plumley. 1988. Old Nubian Texts from the Qasr Ibrim I. London: Egypt Exploration Society.

De Man, P. 1979. Allegories of Reading: Figural Language in Rousseau, Nietzsche, Rilke, and Proust. New Haven, CT: Yale University Press.

De Man, P. 1986. Resistance to Theory. Minneapolis, MN: University of Minnesota Press.

Derrida, J. 1976. Of Grammatology, trans. G. Spivak. Baltimore, MD: Johns Hopkins University Press.

Griffith, F.L. 1913. The Nubian Texts of the Christian Period. Berlin, Germany: Verlag der Königl.

Gumbrecht, H.U. 2003. The Powers of Philology: Dynamics of Textual Scholarship. Chicago, IL: University of Illinois Press.

Gurd, S.A. 2005. Iphigeneias at Aulis: Textual Multiplicity, Radical Philology. Ithaca, NY: Cornell University Press.

Hamacher, W. 1996. 'Lectio': De Man's Imperative. In Premises: Essays on Philosophy and Literature from Kant to Celan, trans. P. Fenves, 181-222. Cambridge, MA: Harvard University Press.

Hamacher, W. 2009. 95 Theses on Philology, trans. C. Diehl. Diacritics 39(1): 25-44.

Hamacher, W. 2010. 95 Thesen zur Philologie. Frankfurt am Main, Germany: Urs Engeler.

Heidegger, M. 2000. Introduction to Metaphysics, trans. G. Fried and R. Polt. New Haven, CT: Yale University Press.

King James Bible Online. http://kingjamesbibleonline.org/.

Mellors, N. 2010. Book A or Megacolon or For \& Against Language. Eindhoven, the Netherlands: Onomatopee.

Mellors, N. and R. Wright. 2012. Interview Conducted at the Time of Ourhouse E3 Feat. Bad Copy at Matt's Gallery, London, 18 April-27 May. This Is Tomorrow, http://www .thisistomorrow.info/viewArticle.aspx? artId=1311. 
Rilly, C. 2010. La méroïtique et sa famille linguistique. Leuven/Paris: Peeters.

Ronell, A. 1989. The Telephone Book: Technology, Schizophrenia, Electric Speech. Lincoln, NE: University of Nebraska Press.

Ronell, A. 2007. The Überreader: The Selected Works of Avital Ronell, ed. D. Davis. Chicago, IL: University of Chicago Press.

Warren, M. 2003. Post-Philology. In Postcolonial Moves: Medieval Through Modern, eds. P.C. Ingham, and M.R. Warren, 19-45. New York: Palgrave Macmillan.

West, M.L. 1973. Textual Criticism and Editorial Technique. Stuttgart, Germany: B.G. Teubner. 